\title{
THE IMPORTANCE OF FINANCIAL ACCOUNTING INFORMATION FOR BUSINESS MANAGEMENT
}

\author{
Erika Besuspariene் ${ }^{*}$ \\ Edita Vitunskaitè, \\ Ričardas Butènas
}

Kauno Kolegija/

University of Applied Sciences, Kaunas, Lithuania

\begin{abstract}
:
Financial accounting provides about $50 \%$ of effective information data. This information can be used for decision making processes in business. Unfortunately, the existing situation shows the issue of financial reporting quality. This may lead to the situation when owners and employees of the companies do not trust financial accounting data and do not use it often for decision making. Therefore, the aim of the research is to assess the areas of financial accounting information used in business management decision making in Lithuanian companies. To investigate the theoretical aspect of the importance of financial accounting information for business management, systemic analysis and synthesis of the theoretical insights of scientific literature were applied. The empirical results are based on a questionnaire survey among Lithuanian companies.
\end{abstract}

Keywords:

accounting information, business, financial accounting, management

\section{INTRODUCTION}

Scientists have still not sufficiently explored the institutional and social aspects of financial accounting. One of the reasons is financial accounting form harmonization or standardization problems, most countries still use diverse forms of accounting, which depend at national level (Hopwood, 2000). Therefore, it is complicated to make business management decisions at international level. Countries are striving for harmonization and since 2016 Lithuania has been making changes in accounting legislation for standardization of accounting in EU. Unfortunately, these frequent legislative changes can cause stress among accountants who quickly and efficiently accept innovations. Therefore, the quality of financial accounting information becomes worse. The level of quality of financial accounting information in Lithuania is low, as it is revealed in the research of the Authority of Audit, Accounting, Property Valuation and Insolvency Management (2017). The analysis of financial statement of 100 companies of Lithuania has revealed that $59 \%$ of good quality financial statements are prepared by the company of accounting service and $50 \%$ of good quality financial statements are prepared by the chief accountant of the company.

According to Ovidia (2013, cited Srivastava, Lognathan, 2016), the financial accounting information provides $46-50 \%$ of effective information data. This is a large part of the information that is useful for business management decisions. Unfortunately, if the accounting information is accurately presented in the financial statements by only $50 \%$ in Lithuania, the effective information data decrease. This can have negative effect on business management decisions. Therefore, the problem of the research is - what is the impact of financial accounting 
information on business management decisions? The aim of the research - to assess the quantity of financial accounting information used on business management decisions in the companies of Lithuania.

Tasks to achieve the set aim:

1. to analyze the importance of financial accounting information for business management.

2. to investigate the relationship between the decision of business management and the use of financial information in Lithuania.

\section{THE IMPORTANCE OF FINANCIAL ACCOUNTING INFORMATION FOR BUSINESS MANAGEMENT}

Financial accounting has various definitions in practice. Unfortunately, according to Černius (2012) the definitions of the concepts of accounting, bookkeeping, financial accounting are used in different terms for describing the same phenomenon and this causes quite a lot of confusion. Therefore, it is necessary to disclose correctly the definition of financial accounting before analyzing its importance.

Various authors and scientists, such as Boudreau, Ramstad (1997), Zabielavičienė (2009), Černius (2012), Gliaubicas (2012), Akhmetshin, Osadchy (2015), Salako, Yusuf (2016) and others discussed the concept of financial accounting. The majority of definitions reveal the same criteria of financial accounting, just a few show different meanings of financial accounting. Financial accounting definition discloses that financial accounting is not only a system of transaction classification and recording, but it is also important for business decision making process.

The analysis of financial accounting definitions allowed to disclose the fact that the main goals of financial accounting is financial information collecting and transforming process (IASC, 1992, cited Krisement, 1997), monetary transactions' classification and recording process (Salako, Yusuf, 2016), application system of accounting rule (Boudreau, Ramstad, 1997), information presented in the annual account (IASC, 1992, cited Krisement, 1997), preparation system of financial statements (Černius, 2012), financial information provision for a user (Spiceland, Sepe, Tomassini, 2001, cited Young, 2006; Samuel, 2013, cited Herath, Melvin, 2017; Akhmetshin, Osadchy, 2015; Sevilengül, 2016, cited Adalı, Kız1, 2017), information about the material and financial standing of a company (Akhmetshin, Osadchy, 2015), source for management accounting (Zabielavičiene; 2009), information for business decision making (Akhmetshin, Osadchy, 2015; Sevilengül, 2016, cited Adalı, Kızıl, 2017).

To sum up, the majority of authors and scientists admit that financial accounting is important for a user, unfortunately just some mention the business decision making process. However, it needs to be specified what financial accounting information for a user is necessary for a decision making process. Accordingly, financial accounting information could disclose the information regarding the economic viability of the company, the performance of the company, the development stage of the company, as well as the risks the company is facing (Florin, 2014). Therefore, traditional financial accounting must assure true and fair view of the company's performance (Zambon, Del Bello, 2005; Yadav, Kumar, Bhatia, 2014). This is necessary for users of financial reporting, as well as for the investors to reduce the risk (Yadav, Kumar, Bhatia, 2014) or "as a management tool for strategic decision making" (Zambon, Del Bello, 2005).

Munteanu, Berechet, Scarlat (2016) explained the importance of financial accounting information for users. The scientists admit the importance of cash flows, because the managerial decisions depend on different activities of cash flows in company. Financial accounting information discloses the size of resources of main activities or investing. Cash flow is acting as a self-financing margin. The financial accounting information could be transformed into financial indicators, which are one of the company's analysis methods for managerial decision. Therefore, financial accounting information contributes to the measurement of company's financial indicators, developing of financial and economic processes, evaluating of selffinancing and generating cash capacity. Following B. Gibson (1992), financial accounting plays the role in the business management decision making of small companies, therefore the access to financial accounting information must be ensured for owners. The author admits that the use of financial accounting information for decisions of financial data planning can be regarded as rational decision making.

The authors of the article admit that the main aspect of financial information is quality. To ensure this, what is needed is that financial accounting has rules and the system users can make rational decisions. According to Achim and Chis (2014), the quality of financial information is not easily quantified, and it cannot be observed directly. A user of financial information has different expectations and perceptions regarding what information is useful and has good quality. It is important to add, that financial accounting quality depends on accounting sustainability. G. Lamberton (2005) admits, that "business decision makers require a balanced information set, including economic, social and environmental information if decisions are to achieve the multidimensional goal of sustainability". S. Schaltegger, R. L. Burritt (2010) debate about two lines of accounting sustainability, one illustrates philosophical accountabilities and the other one the management perspective. Therefore, according 
to G. Lamberton (2005), "the provision of sustainability accounting information to internal users would focus on the provision of relevant and decision useful information to management."

Financial accounting information, which is stored in financial accounting systems, directs us to control mechanisms of company (Bushman, Smith, 2001). One of control mechanisms is a right decision of business management. According to A. Látečková (2014), accounting is a valuable source of data for "financial planning, economic analysis, cost controlling, strategic controlling, liabilities controlling, controlling of sales, marketing analysis and planning, profit managing, cash flow and others".

Every business unit competes in a specific environment of market. In order to adapt and succeed in the market changes, companies use various business strategies. Business firms that are more familiar with the external environment, know their shortcomings and benefits, and have more opportunities to make effective changes to their strategies, and are much more flexible (Valentavičius, 2009). Therefore, business process management requires holistic management understanding, involvement, process-aware information systems, welldefined accountability and a culture that is receptive to business processes (De Bruin, M. Rosemann, 2005). It is important to admit, that accounting processes are part of business processes (Spathis, Constantinides, 2004). Therefore, to control business processes and make necessary decisions, business owners and employees have to follow financial accounting data.

Business decision making depends on companies' strategy forces. Many researchers explained different types of theoretical models of strategies which could be used by enterprises. One of them is Porter's five forces model
(Porter, 1989). According to S. Valentavičius (2009), the main purpose of combination of Porter's five forces is to explain the level of competition in the market; also, it helps to find a niche in the market where the organization could best defend itself against these forces. Competitive environment is also created by those market players who have nothing in common with the competition, e.g. consumers.

This business strategy model is designed by analyzing literature on micro-economics through five forces which are the bargaining power of the buyers, entry barriers, rivalry, substitutes and the bargaining power of the suppliers (Grundy, 2006). Following these five forces and ensuring business viability can help to financial accounting data analysis. For example, the bargaining powers of the buyers are one of the most important criteria in the process of planning companies' revenue. To ensure that sales companies can work with sales controller. T. Hyvonen, J. Jarvinen, J. Pellinen (2015) admit that sales controller job should focus on financial reporting and data combining accounting, as well as managerial roles. Buyers monitoring is also an important process in business management. Here - it is important to analyze a buyer's debt. Z. Ramly (2013) admits that financial reporting is also the process of assessing the extent of debt risk the oversight mechanism.

After summing up literature analysis about the importance of financial accounting information, it can be concluded that financial accounting has various goals. The most important goal is financial accounting information use for business decisions. Depending on various information, users' purpose can be different, but they expect true and fair image of a company. Nowadays, sustainable accounting, which plays the main role in the decision making, can ensure true and fair image of a company.

Figure 1. Research model and hypotheses

\begin{tabular}{|l|l|l|}
\hline Bargaining power of the buyers \\
Bappliers \\
\hline Entry barriers
\end{tabular}




\section{METHODOLOGY}

Today, in terms of accounting reliability, it could be said that users do not trust financial accounting data. Therefore, the purpose of this research is to reveal business confidence in accounting data and the understanding of the use of financial accounting information. The aim of the research was to examine the importance of financial accounting information for business management in Lithuania. Summarizing the theoretical aspects and the results of scientific research, the research hypotheses are formed (see, figure 1).

As we can see in Figure 1, the research model has 14 hypotheses. H1-H5: Positive relationship existing between companies that believe that financial accounting is used as information for business decision making and opinion that financial information can solve problems of the bargaining power of the buyers, the bargaining power of the suppliers, entry barriers, rivalry and substitutes. H6-H14: Positive relationship existing between companies that believe that financial accounting is used as information for business decision making and financial information for Financial planning, Economic analysis, Cost controlling, Strategic controlling, Liabilities controlling, Controlling of sales, Marketing analysis and planning, Profit managing, Cash flow controlling.

In order to confirm or deny these hypotheses, an empirical investigation was made using a quantitative research method - a questionnaire survey. The questionnaire consists of two parts: in the first part, respondents were exposed to demographic questions aimed at identifying the respondent's duties, the type of company, the size of the company, the activities of the company and the number of years of the company's activity on the market; the second part formulates the statements evaluated by the five-point Likert scale (5 - strongly agree, 4 - agree, 3 have no opinion, 2 - disagree, 1 - strongly disagree).

At the beginning of 2018, according to the data of the Department of Statistics of the Republic of Lithuania, there were 83439 companies operating in Lithuania. According to Yamane (1967, cit. Izra, 1992), a simplified sample calculation formula is used to get 395 respondents to gain 95 percent of credibility. A survey of 398 respondents requires significant time and financial costs, therefore 38 respondents were interviewed. In this case, the error rate is $16 \%$. The survey was conducted in July-August of 2018 and it was conducted using an online survey.

38 respondents participated in a survey: 3 company managers, 7 middle managers, 16 sales managers, 12 other employees. The research involved 15 small, 11 small, 4 medium and 8 large enterprises. 19 respondents represented enterprises operating in the market of up to 2 years, 9 respondents operating in the market from 3 to 5 years, 5 respondents - companies operating from 6 to 10 years, and 5 respondents - companies operating from 10 to 15 years. This distribution of respondents is believed to be sufficient to obtain reliable results.

Table 1. Interpreting the Size of a Correlation Coefficient

\begin{tabular}{cccc}
\hline Size of Correlation & Interpretation & Size of Correlation & Interpretation \\
\hline $\mathbf{0 . 9 0}$ to $\mathbf{1 . 0 0}$ & Very high positive correlation & $\mathbf{- 0 . 9 0}$ to $\mathbf{- 1 . 0 0}$ & Very high negative correlation \\
\hline $\mathbf{0 . 7 0}$ to $\mathbf{0 . 9 0}$ & High positive correlation & $\mathbf{- 0 . 7 0}$ to $\mathbf{- 0 . 9 0}$ & High negative correlation \\
\hline $\mathbf{0 . 5 0}$ to $\mathbf{0 . 7 0}$ & Moderate positive correlation & $\mathbf{- 0 . 5 0}$ to $\mathbf{- 0 . 7 0}$ & Moderate negative correlation \\
\hline $\mathbf{0 . 3 0}$ to $\mathbf{0 . 5 0}$ & Low positive correlation & $\mathbf{- 0 . 3 0}$ to $\mathbf{- 0 . 5 0}$ & Low negative correlation \\
\hline $\mathbf{0 . 0 0}$ to $\mathbf{0 . 3 0}$ & Negligible correlation & $\mathbf{0 . 0 0}$ to $\mathbf{- 0 . 3 0}$ & Negligible correlation \\
\hline
\end{tabular}

Source: M. M. Mukaka (2012)

In order to find out more about the use of financial accounting for business decisions, the statistical relationship between various factors was determined by using the Spearman correlation coefficient. The obtained results are estimated on the basis of the interpretations of correlation coefficients presented by M. M. Mukaka (2012) (see Table 1). The calculations are performed using the package of statistical analysis SPSS.

\section{THE RESULTS OF THE RESEARCH}

Table 2 reports the value of the Spearman rank correlation coefficient between financial accounting perception that financial accounting is used as information for business decision making and each of the issues (the bargaining power of the buyers, the bargaining power of the suppliers, entry barriers, rivalry and substitutes). 
Table 2. Spearman Rank Correlation Coefficient

\begin{tabular}{lc}
\hline $\begin{array}{c}\text { Financial accounting infor- } \\
\text { mation can help to address } \\
\text { the following issues: }\end{array}$ & $\begin{array}{c}\text { Financial accounting is used } \\
\text { as information for business } \\
\text { decision making }\end{array}$ \\
\hline $\begin{array}{c}\text { of the bargaining power of } \\
\text { the buyers }\end{array}$ & 0.104 \\
\hline $\begin{array}{c}\text { of the bargaining power of } \\
\text { the suppliers }\end{array}$ & 0.283 \\
\hline of entry barriers & $0.400^{*}$ \\
\hline of rivalry & $0.365^{*}$ \\
\hline of substitutes & $0.341^{*}$ \\
\hline * Correlation is significant at the 0.05 level $(2$-tailed).
\end{tabular}

In regression, a significant low positive relation is found between financial accounting perception that financial accounting is used as information for business decision making and decision of entry barriers (value $=0.400$ ), rivalry (value $=0.365$ ) and substitutes (value $=0.365)$. Regression shows a negligible correlation between financial accounting perception that financial accounting is used as information for business decision making and decision of the bargaining power of the buyers, of the bargaining power of the suppliers.

In conclusion, business agrees that financial accounting information is used to make business decisions, considers financial accounting information to be useful in assessing barriers to entry and restricts the ability of the market to evaluate existing substitutes. At the same time, the results have shown that business question the benefits of combining financial accounting information with buyers and suppliers. Such results may have appeared due to the fact that business does not trust financial accounting data and does not expect buyers or suppliers to receive fair financial statements. However, an additional study should be undertaken to assess this.

Table 3 reports the value of the Spearman rank correlation coefficient between financial accounting perception that financial accounting is used as information for business decision making and each of the cases using accounting information.

Table 3. Spearman Rank Correlation Coefficient

\begin{tabular}{cc}
\hline $\begin{array}{c}\text { Financial information } \\
\text { using for: }\end{array}$ & $\begin{array}{c}\text { Financial accounting is used as } \\
\text { information for business } \\
\text { decision making }\end{array}$ \\
\hline Financial planning & 0.158 \\
\hline Economic analysis & $0.428^{\star *}$ \\
\hline Cost controlling & 0.152 \\
\hline Strategic controlling & $0.502^{\star *}$ \\
\hline
\end{tabular}

\begin{tabular}{lc}
\hline Liabilities controlling & $0.631^{\star *}$ \\
\hline Controlling of sales & $0.461^{\star *}$ \\
\hline $\begin{array}{l}\text { Marketing analysis } \\
\text { and planning }\end{array}$ & $0.441^{\star *}$ \\
\hline Profit managing & $0.341^{*}$ \\
\hline Cash flow controlling & 0.262 \\
*. Correlation is significant at the 0.05 level (2-tailed). \\
$* *$ Correlation is significant at the 0.01 level (2-tailed).
\end{tabular}

In regression, a significant moderate positive relation is found between financial accounting perception that financial accounting is used as information for business decision making and financial accounting application for strategic controlling (value $=0.502$ ) and liabilities controlling (value $=0.631$ ). Regression shows a significant low positive relation between financial accounting perception that financial accounting is used as information for business decision making and the application of financial accounting for economic analysis (value $=0.428$ ), controlling of sales (value $=0.461$ ), marketing analysis and planning (value $=0.441$ ) and profit managing (value $=0.341$ ). Negligible correlation exists between financial accounting perception that financial accounting is used as information for business decision making and the application financial accounting for financial planning, cost controlling and cash flow controlling.

In conclusion, business uses financial information to make decisions related to sales (controlling of sales, marketing analysis and planning, profit management), and the control of goods and materials (liabilities control). When assessing business viability, business uses financial accounting data only to control strategies, while financial planning, cost control and cash flow control are not evaluated by using financial accounting data. An additional study should be made to evaluate the causes.

\section{CONCLUSION}

1. Information regarding financial accounting is important for its users in the process of making various decisions. As regards small or large companies - the advantages of financial accounting information are different. Literature analysis showed that the importance of financial accounting information could be revealed through Porter's five forces. Financial accounting information can be used for buyers monitoring and debt risk controlling. Also, it disclosed the size of resources of main activities or investing, finance planning, ensuring cash flow and strategic planning. Depending on the 
company's size, the list of financial accounting information could be different. Surely, financial accounting information must assure true and fair image of the company. Therefore, today it is necessary to discuss sustainable accounting. Sustainable accounting can have a positive impact on business decisions.

2. The empirical research revealed that Lithuanian companies mostly use financial accounting information to make decisions related to sales (controlling of sales, marketing analysis and planning, profit management). Following Porter's five forces, Lithuanian companies apply financial accounting information for making decisions related to entry barriers, rivalry and substitutes. It looks strangely, but Lithuanian companies do not tend to apply financial accounting information to financial planning, cost control and cash flow controlling.

\section{LITERATURE}

Achim, A. M., \& Chiş, A. O. (2014). Financial accounting quality and its defining characteristics. SEA: Practical Application of Science, 2(3), 93-98.

Adalı, S., \& Kizıl, C. (2017). A Research on the Responsibility of Accounting Professionals to Determine and Prevent Accounting Errors and Frauds: Edirne Sample. EMAJ: Emerging Markets Journal, 7(1), 53-64.

Agriyanto, R., Rohman, A., Ratmono, D., \& Ghozali, I. (2016). Accrual based accounting implementation: an approach for modelling major decisions. Risk Governance \& Control: Financial Markets and Institutions, 6(4), 531-539.

Akhmetshin, E. M., \& Osadchy, E. A. (2015). New requirements to the control of the maintenance of accounting records of the company in the conditions of the economic insecurity. International Business Management, 9(5), 895-902.

Authority of Audit, Accounting, Property Valuation and Insolvency Management (2017). Financial statements quality review investigation. Available on http://www. bankrotodep.lt/assets/Apskaita/FA-kokybs-tyrimoAPZVALGA-SVETAINEI.pdf

Boudreu, J., W., Ramstad, P. M. (1997). Measuring intellectual capital: Learning from financial history. Human Resource Management, 36 (3), 343-356.

Bushman, R. M., \& Smith, A. J. (2001). Financial accounting information and corporate governance. Journal of Accounting and Economics, 32(1), 237-333.

Černius, G. (2012). The Influence of Misleading Terminology on the Company's Finances. Societal Studies, 4(2), 539-558.
De Bruin, T., Rosemann, M. (2005). Towards a business process management maturity model. Available on https://eprints.qut.edu.au/25194/1/25194_rosemann_ 2006001488.pdf

Dudin, M. N., Prokofev, M. N., Fedorova, I. J. E., Frygin, A. V., \& Kucuri, G. N. (2015). International Practice of Generation of the National Budget Income on the Basis of the Generally Accepted Financial Reporting Standards (IFRS). Asian Social Science, 11 (8), 119126.

Florin, B. (2014). Development of decision making by managers with financial and accounting information. The Annals of the University of Oradea, 1, 837-844.

Gibson, B. (1992). Financial information for decision making: An alternative small firm perspective. The Journal of Entrepreneurial Finance, 1 (3), 221-232.

Gliaubicas, D. (2012). Research of the evolution of management accounting in context of economic changes. Science and Studies of Accounting and Finance: Problems and Perspectives, 8 (1), 59-65.

Grundy, T. (2006). Rethinking and reinventing Michael Porter's five forces model. Strategic Change, 15(5), 213-229.

Herath, S. K., \& Melvin, A. (2017). The Impact of IFRS Adoption on Corporate Income Taxation: A review of literature. International Journal of Business Management and Commerce, 2 (1), 1-9.

Hopwood, A. G. (2000). Understanding financial accounting practice. Accounting, Organizations and Society, 25 (8), 763-766.

Israel, G. D. (1992). Determining sample size. Available on https://a7852d97-a-62cb3a1a-s-sites.googlegroups. $\mathrm{com} /$ site/estadisticayunpocomas/tama\%C3\%B1 omuestra.pdf?attachauth=ANoY7crhyuyeiuavCd110rK0NngTTaeogcRxiRatvXw7rxL7qO3i3m5BASg6raJCX7yA8V8gq-tiKf2itsLRiNBzJd42l P4Mn-i4D-UqsCLkILP09DXwtJekEyexxAr2u q_7IYCzjcwrWym1jHqPAhHM4Zr6-Ge1QskNzKn3loV7yDLr14Pvm6BJpmNNZXmlNxh1SXIK3DwhAkjhsvp2CRkknHwqufVRCyKIyGRtwbcVFLI0O ZR9F8\%3D\&attredirects $=0$

Krisement, V. M. (1997). An approach for measuring the degree of comparability of financial accounting information. European Accounting Review, 6(3), 465-485.

Lamberton, G. (2005). Sustainability accounting - a brief history and conceptual framework. In Accounting Forum, Elsevier, 29 (1), 7-26.

Mukaka, M. M. (2012). A guide to appropriate use of correlation coefficient in medical research. Malawi Medical Journal, 24(3), 69-71.

Munteanu, V., Berechet, M. C., Scarlat, L. M. (2016). Financial accounting information system-premise of managerial act. Knowledge Horizons. Economics, 8 (2), 88. 
Porter, M. E. (1989). How competitive forces shape strategy. In Readings in Strategic Management (pp. 133143). Palgrave, London.

Ramly, Z. (2013). Corporate governance, shareholder monitoring and cost of debt in Malaysia. International Journal of Social, Behavioral, Educational, Economic, Business and Industrial Engineering, 7 (4), 1062-1073.

Salako, M. A., Yusuf, S. A. (2016). Cost Accounting: A Pivotal Factor of Entrepreneurial Success. Available on https://mpra.ub.uni-muenchen.de/69101/1/MPRA_ paper_69101.pdf

Schaltegger, S., \& Burritt, R. L. (2010). Sustainability accounting for companies: Catchphrase or decision support for business leaders? Journal of World Business, 45 (4), 375-384.

Spathis, C., \& Constantinides, S. (2004). Enterprise resource planning systems' impact on accounting processes. Business Process Management Journal, 10 (2), 234-247.

Srivastava, P., \& Lognathan, M. S. (2016). Impact of accounting information for management decision making. IJAR, 2 (5), 171-174.
Valentinavičius, S. (2009). Theoretical aspects of enterprise business strategy formation. Business: Theory \& Practice, 10 (2), 130-141.

Weihrich, H. (1982). The TOWS matrix-A tool for situational analysis. Long Range Planning, 15 (2), 54-66.

Yadav, B., Kumar, A., \& Bhatia, B. S. (2014). Concept of creative accounting and its different tools. International Journal of Management and Social Sciences Research (IJMSSR), 3(2), 66-74.

Young, J. J. (2006). Making up users. Accounting, Organizations and Society, 31(6), 579-600.

Zabielavičienè, I. (2009). Methodological Aspects of Accounting and Analysis of Innovations. Ekonomika ir vadyba: aktualijos ir perspektyvos, (2), 130-142.

Zambon, S., \& Del Bello, A. (2005). Towards a stakeholder responsible approach: the constructive role of reporting. Corporate Governance: The International Journal of Business in Society, 5(2), 130-141. 